\title{
TOWARD THE FORMATION OF A PARTISAN ALIGNMENT IN FRANCE
}

\section{Roy Pierce}

This article investigates the extent to which and the ways in which a basic partisan alignment appeared to be forming in France between 1958 and 1988. During that period, the incidence of party identification rose from abnormally low to normal levels, and the composition of the alignment evolved from indeterminacy, through a left-right standoff, to Socialist party predominance. The basic question asked is how a partisan alignment is created in the first place. The main elements of the answer suggested are by simplifying, clarifying, and stabilizing the terms of electoral choice. This process is traced closely, with special reference to the incidence of $P I$ and the composition of the alignment by age in 1988, and including a comparison between France in 1968 and the U.S. in 1932. Finally, the fragility of the 1988 alignment is underscored. Comparatively new and shaped mainly by the partisan identifications of the younger citizens, the 1988 alignment was vulnerable to any weakening of the conditions that contributed to creating it. The party with the most to lose was the Socialist party, which had gained the most while the party system stabilized and the incidence of party identification rose.

The purpose of this article is to investigate the extent to which, and the ways in which, a basic partisan alignment appeared to be forming within the French electorate during the thirty years between 1958 and 1988.

The implications of the subject are twofold. On the one hand, our investigation will shed light on the relationship between French mass partisan orientations and the structure of the French party system. During most of the postwar era, the French party system, by virtually any measure, has been highly unstable. Whether one considers the life expectancy of legislative electoral parties and parliamentary groups, or the volatility of legislative electoral results, the French party system has displayed a high degree of inconstancy. In more recent years, however, there have been signs of at least some dampening of what Charles de Gaulle referred to in 1946 as

Roy Pierce, Department of Political Science, University of Michigan, Ann Arbor, Michigan 48104.

This is a revised version of a paper that was originally presented at the 1991 Annual Meeting of the American Political Science Association, Washington, D.C. 
"France's perpetual political effervescence." The symptoms of political instability have certainly not disappeared from France, but for the two decades prior to the presidential and legislative elections of 1988, the party system displayed a rare degree of both clarity and continuity. Stability at the level of the party system should both promote and reflect stability in underlying mass partisan attachments.

On the other hand, while the literature pertaining to party identification is enormous, there has been virtually no empirical investigation of how a partisan alignment is created in the first place, at least in contemporary conditions. We of course know in a broad sense, on the basis of numerous historical studies, and as systematized for Western Europe by Lipset and Rokkan (1967), a great deal about the relationship between parties and basic social cleavages. We know less about the processes by which those social cleavages become translated into specific partisan attachments. Studies of party identification include analyses of both historical and presumably current cases of "realignment" or "dealignment," but these share the common assumption that there was some ongoing partisan alignment already present from which elements of the electorate could, in changed circumstances, distance themselves. Such studies all ask the question: How does an electorate move from one kind of partisan alignment to another? In this article, I ask the question: How does an electorate move from what is virtually no partisan alignment at all to an alignment that appears to be at least minimally capable of both stabilizing the allocation of the mass partisan vote and setting limits to the capacity of political elites to recast the shape of the party system by splitting old parties or forming new ones? In that fashion, this paper will wed local French political phenomena to the theory of elections that centers around the core concept of party identification.

\section{MASS PARTISAN ATTACHMENTS AND THE PARTY SYSTEM}

France seems to hold the world record for electoral volatility. Mair (1989) reports that France not only experienced more high-volatility elections during the post-World War II period than any other country surveyed, but it also had the most high-volatility elections during the entire century between 1885 and 1985. The long-term character of that pattern should be a powerful caution against attributing too much importance to contrary phenomena that may turn out to be short-lived. We will be sensitive to that danger. That does not mean, however, that we should simply brush aside whatever opposing data come our way.

It is important to keep in mind that this characteristic electoral volatility is less the result of inconstancy in the partisan choices of French voters 
than of the propensity of French political elites to alter the terms of what Lancelot (1986, p. 20) has labeled the "political supply." Converse and Pierce (1986) have shown that despite the French record of high net aggregate instability, when one controls for the constancy of partisan (or candidate) offerings from one electoral period to the next, French voters do not appear to be any more fickle in their electoral choices than their U.S. counterparts, and in some situations they are actually more loyal politically than comparably situated U.S. voters. ${ }^{1}$

The high-volatility postwar elections identified by Mair (1989) were the legislative elections of 1951, 1956, 1958, and 1962. There were surely some large gross shifts in electoral support for the same party during those years, such as the drop in the proportion of the vote for the Communist party from 1956 to 1958, and the gain in the vote for the Gaullists in 1968 relative to 1967 . But the period also witnessed numerous changes in the terms of electoral choice presented to the voters, of which the most destabilizing were almost surely the successive incarnations of the Gaullist party, but also including the formation of such purely temporary electoral organizations as the Poujadists and Pierre Mendès-France's Republican Front.

The implications of this unceasing tinkering by the elites with the nature of the electoral alternatives offered to the voters for the breadth and depth of mass linkages with the parties were only tangentially appreciated during the early part of the period. Williams (1964, pp. 151-152) raised the issue of the electoral worth of the party label during the Fourth Republic, but only in the context of maintaining party discipline among Conservatives in Parliament. An IFOP poll conducted in 1952 (Sondages, 1952) highlighted the limited extent to which French voters had confidence in the parties for which they reported voting at the most recent election. Another IFOP poll (Fougeyrollas, 1963, p. 180) carried out in 1956 indicated that more than 40 percent of the electorate either would not or could not name a party or political group that answered their needs. It was not until Converse and Dupeux (1962) reported on the comparatively low incidence of party identification in France, as revealed at surveys conducted in connection with the 1958 legislative elections, and linked it with the potentiality for mass electoral support for "flash" parties, that the reciprocal relationship between the instability of the French party system and the comparatively underdeveloped nature of French partisan attachments could be understood.

During the late 1950s, the mass-elite electoral connection in France was confined in a circuitous pattern from which there could be no quick or easy escape. Only about half of the electorate was relatively firmly anchored to an existing political party. The remaining half was accessible to whichever parties were most attractive to individual voters at any given electoral moment. ${ }^{2}$ New parties, which were rarely in short supply, could count on a 
large pool of potential supporters, and existing parties-particularly but not exclusively those on the right and in the center of the spectrum - were constantly under threat. The reserve army of new voters, combined with unattached older ones, produced a continuing supply of electoral recruits for France's political entrepreneurs. These, however, did not always give their newfound followers the opportunity to vote for their parties twice in a row, with the result that a party's electoral gains at one election were dissipated at the following one. Charles de Gaulle's RPF (Rassemblement du Peuple Français) halved the electoral strength of the MRP (Mouvement Républicain Populaire) in 1951 but no longer existed in 1956, while the Poujadists won almost 12 percent of the votes in 1956 but fielded only a handful of candidates in 1958.

At the same time as the large number of unattached French voters provided mass support for new parties, the unstinting efforts of the political elites to create them undermined the likelihood that the incidence and intensification of party identification would grow at more than a snail's pace. The kaleidoscopic character of the party system meant that there were few stable partisan referents. Only the traditional leftist parties, the Communists, Socialists, and Radical-Socialists, had the longevity and continuity of nomenclature and symbolism to be enduring objects of psychological attachment. Except for those parties, the possibility of intergenerational transmission of partisanship was virtually suspended. The endemic discontinuity of partisan offerings weakened the probability that freshly acquired partisan identifications would become reinforced through repeated expression. The underdeveloped status of party identification in France rewarded the efforts of partisan innovators, and those efforts in turn ensured that partisan identifications would not easily multiply or intensify.

At the outset of the French Fifth Republic, therefore, the incidence of party identification was so limited and the party system so fluid that it hardly makes any sense to speak of the existence at that time of some partisan alignment based on enduring party allegiances. The electorate was so heavily populated with citizens without any abiding party attachments that electoral outcomes could be expected to be affected as much by other factors as they were by partisan loyalties. Party identifications would have to become more numerous and more firmly implanted before it would be possible to talk about a partisan alignment in France.

The main condition for the diffusion and intensification of partisanship at the mass level was modification of the party system in the direction of simplification and stability. Developments consistent with those outcomes did in fact occur during the Fifth Republic. As a result, the incidence of party identification increased, at first slowly, and later, almost surely, more rapidly. By the late 1980s, the incidence of party identification in France 
had risen to the level that Converse (1969) had determined to be characteristic of a mature party system. With approximately the same proportion of the electorate identifying with a party in France as normally do in the other developed democracies for which we have the relevant data, it has become possible to speak of the existence of a given partisan alignment. The remainder of this paper will chart the rise in the incidence of party identification in France, analyze the political composition of the newly formed partisan alignment, and assess the probability that this alignment will endure.

\section{THE EMERGENCE OF A PARTISAN ALIGNMENT}

There is no longitudinal record of abiding partisan attachments in France comparable to the series of measurements of party identification contained in the United States National Election Studies or the equivalent studies that have been conducted elsewhere, notably in the Scandinavian countries. There are, of course, numerous studies that purport to measure party identification in France, but these invariably provide the respondents with a list of parties from which they are asked to choose. This interviewing technique inflates the proportion of respondents claiming to identify with a party, at the same time as it prevents expression of the idiosyncratic responses that an open-ended question permits. Converse and Pierce (1986, pp. 58-61) have shown that in 1967 the median number of parties that the French electorate could spontaneously recall was less than four. When respondents were shown a list of ten parties, however, the number that they could recognize was larger. It does not seem to be unreasonable to count as true identifiers only those people who can spontaneously recall the name of the party to which they claim to be habitually close. ${ }^{3}$

In order to ensure the maximum degree of cross-time continuity in measurement of party identification in France, we will rely here only on three studies: the Converse/Dupeux study of 1958 , to which we have already referred; the Converse/Pierce study conducted during the late 1960s (Converse and Pierce, 1986, Chap. 3); and a postpresidential election survey conducted by SOFRES for the author in 1988, in connection with a larger study of presidential selection in France and the United States. ${ }^{4}$ The basic question employed in 1958, which was formulated by Georges Dupeux, was "Quel est le parti dont vous vous sentez le plus proche?" (Which party do you feel closest to?) For the Converse/Pierce surveys of the late 1960 s, the word habituellement was inserted, so that the question read, "Which party do you usually feel closest to?" That same question wording was retained for the 1988 survey. The questions were completely openended. The respondents were given the opportunity to cite any party or 
group they wished, in their own words, without prompting or the use of aids of any kind. ${ }^{5}$

We have already recalled that in the late $1950 \mathrm{~s}$, the incidence of party identification in France was so low-some twenty percentage points less than it was at the same era in the United States (Converse and Dupeux, 1962) - that it would be futile to think in terms of there being some partisan alignment operative at the time. By the late 1960 s, that comparatively low level had risen slightly, although the convulsive events of May 1968 produced some sharp discontinuities between the levels registered at the legislative elections of spring 1967 and summer 1968. Nevertheless, the direct indications that the incidence of party identification had increased over the previous decade, combined with ancillary evidence indicating that more French children were being socialized politically than had previously been the case, led Converse and Pierce (1986, Chap. 3) to the cautious conclusion that the incidence of partisanship would increase still further in the future.

Our postelectoral survey of 1988 furnishes decisive evidence that such a development did in fact occur during the intervening two decades. Some 71 percent of the respondents reported a discrete partisan identification, a value that fully matches those reported for strict party identifiers (i.e., excluding leaners) in the United States during the 1950s and 1960s, against which the earlier French levels had seemed paltry, and even slightly exceeds U.S. proportions during the 1980s.

The incidence of party identification recorded in 1988 suggests strongly that France had by then, and possibly even earlier, reached the equilibrium level of mass partisanship that Converse $(1969, \mathrm{p}$. 146) had estimated to be slightly more than 70 percent of the electorate. ${ }^{6}$ This result is doubly satisfying. On the one hand, it can be taken as a confirmation of the validity of Converse's model of the intergenerational transmission of partisanship. On the other hand, it reinforces our confidence in the findings of our 1988 survey. The level of partisanship recorded for France in 1988 was just about what it should have been. ${ }^{7}$ Between 1958 and 1988, therefore, the incidence of partisanship in France rose to a level typical of democracies with mature party systems, in effect embracing as large a proportion of the electorate as can probabilistically be expected to identify with a party.

At the same time as the incidence of partisanship rose, the contours of the political alignment it reflected also underwent significant change. If it is not realistic to conceive of a basic partisan alignment during the late $1950 \mathrm{~s}$, it is reasonable to think in such terms for the late 1960s, when party identifications were more widespread than they had been earlier. The underlying political balance at that time was such that leftist and rightist party identifiers were virtually equal in numbers. A decade of Gaullist rule after 1958 had made the Gaullist party the beneficiary of more identifiers than any 
other single party enjoyed, but the Communist and Socialist parties combined, in more or less equal proportions, attracted more support than the Gaullist party did. The distribution of partisanship throughout the electorate was such that it could not be said, in 1967, that either leftists or rightists enjoyed any underlying, long-term electoral advantage. The closeness of the 1967 legislative elections reflected the even balance of left-right partisan attachments.

The configuration of partisan attachments was very different in 1988, when, as we have seen, these were also more numerous than they had been two decades earlier. In 1988, the underlying partisan alignment strongly favored the leftist parties in general and the Socialist party in particular. More than 40 percent of our 1988 sample electorate identified with a left-wing party in 1988 , while only some 30 percent identified with a rightist party. The leftists, however, were overwhelmingly attached to the Socialist party, while the rightists divided their allegiances between the neo-Gaullist RPR (Rassemblement pour la République) and the neo-Giscardian UDF (Union pour la Démocratie Française). Some two-thirds of the French voters who identified with a left-wing party (and almost half of the citizens who identified with any party) identified with the Socialist party. The largest right-wing party, the RPR, attracted the loyalties of less than half of the rightist identifiers, while the UDF enjoyed the allegiance of less than a third of them.

Between the late 1960s and the late 1980s, the underlying pattern of party identification in France was transformed. The incidence of party identification rose to the level characteristic of other democracies with well-established party systems. And the balance of professed partisan attachments shifted markedly from a virtual left-right standoff to the advantage of the leftist parties in general and the Socialist party in particular.

In the absence of comparable measures of party identification in France between those two limiting dates, it is impossible to reconstruct in detail how the partisan alignment of 1988 came about. But guided by the cluster of theory surrounding the concept of party identification, and relying on our soundings of the French electorate in 1967 and 1988, we can put the main pieces of the puzzle together in a way that renders the development intelligible. The puzzle itself contains two elements. One is why the incidence of partisanship rose. The other is why the balance of partisan orientations moved to the advantage of the Socialist party.

\section{WHY THE INCIDENCE OF PARTY IDENTIFICATION INCREASED}

It is necessary to distinguish between two main routes toward the acquisition of a partisan attachment: one that passes through familial political socialization, and another that does not. In the former case, children de- 
velop some sort of political consciousness in response to messages they receive from their parents. Later, when these children become adults and make an independent entry into political life, they show a high propensity to acquire an abiding partisan identification. Children who receive no such familial political initiation can, of course, also develop long-term partisan attachments, but - at least in France and the United States during the late 1950 s and $1960 \mathrm{~s}$ - they did so at a considerably lower rate. Powerful forces were at work in France during the two decades preceding the presidential election of 1988 that almost surely augmented the number of French citizens who acquired partisan attachments via one route or the other.

During the 1950s and 1960s, the incidence of partisan identification was low in France not only because of the size and complexity of the party system, but also because a comparatively small proportion of the adults of those years experienced familial political socialization when they had been children. French families appear to have operated under a reticence norm relating to political matters that impeded the development of the kind of political orientations that contribute to the acquisition of partisanship in young adulthood. This norm was still clearly operative as late as 1970 , but there was also evidence in the late 1960 s to indicate that it was weakening. ${ }^{8}$ By 1988, the French electorate contained a larger proportion of people who had received some sort of familial political socialization than had been the case in earlier years. ${ }^{9}$ As those people tend to acquire a party identification more frequently than people who come from families that are noncommunicative politically, the proportion of party identifiers also rose.

This silent but inexorable impact of changing familial mores was related to other, more obvious forces at work between the late 1960s and the late 1980 s that in all probability contributed to the increase in the incidence of party identification among both people who had enjoyed the benefit of prior political socialization and those who did not. The most important of these is that the level of political interest rose enormously between 1967 and 1988. Three times as many people professed having "a lot" of interest in politics in 1988 as did so in 1967, while only about one third as many indicated that they had no interest in politics at all. Expressed in terms of mean scores, political interest rose by about one fifth across the entire electorate between 1967 and 1988.

Some of this increase in political interest was due to the increased education of the 1988 electorate compared with the 1967 one. In 1967, almost three-fourths of the electorate had received only a primary school education, while well under 10 percent had gone to a university or other institution of higher learning. In 1988, about the same proportion of the population (some $25 \%$ ) received a higher education as received only a primary school education. But greater educational opportunities are not the whole 
story. Interest in politics increased within every stratum of the population in educational terms. If the degree of political interest by educational level had remained the same in 1988 as it had been in 1967, overall political interest would have increased only by somewhat more than 10 percent over the 1967 mean, as compared with the 20-percent increase actually recorded.

Other factors conducive to increasing political interest had to be at work also. Almost surely, one of these was increased exposure to television. The decade of the 1970s was the period when French homes became saturated with television sets. These conveyed political information in an attractively packaged form that gained the attention of people for whom the other mass media were either unappealing or unavailable.

But even more important than the increased flow of information, in our opinion, was the simplification of political conflict in France between the late $1960 \mathrm{~s}$ and the late $1980 \mathrm{~s}$, as the result of the creation of two broad competing electoral coalitions that regularly opposed each other at every presidential and legislative election (except the presidential election of 1969).

The neatness and clarity of this two-bloc system was a far cry from the extremely complicated form that French politics had displayed prior to the mid-1960s. Earlier, the party system was highly fractionalized; unstable coalition governments reduced political accountability; and even after the establishment of the Fifth Republic in 1958, the dimensions of political conflict were multiple and various. French citizens thought that there were too many political parties; the political scene was too crowded and confusing to engage the attention of a large fraction of the electorate.

This situation began to change in the early $1960 \mathrm{~s}$, and was completely transformed at the presidential election of 1965, when the stark secondballot confrontation between Charles de Gaulle and Francois Mitterrand symbolized a new kind of politics that was easy for ordinary citizens to understand. The creation of a Gaullist bloc, on the one hand, and a leftist bloc, on the other hand, produced a pseudo-two-party system that simplified the political alternatives facing the public.

Naturally, it took time for this new and more transparent political structure to become clearly established in the mass electorates perceptions. Inevitably, however, the consistency with which conflict between two coalitions characterized political competition across the presidential elections of 1974 and 1981, and the legislative elections of 1973, 1978, and 1981, made politics more intelligible and attracted the attention of people who would have been discouraged by more complex patterns of the kind that de Gaulle had referred to as the "games, poisons and delights" of the system. French political elites continued to allow themselves the indulgence of a 
multiparty system, but its regular division into two competing electoral blocs, corresponding to a governing majority and a more or less united opposition, conferred a meaning to partisanship that had been lacking before. Individual parties could have particular policy preferences and distinctive leaders, but each party occupied a clearly visible position within one major bloc or the other. For two decades, the French political system not only permitted the more involved voters to pick and choose among multiple parties on the basis of complex policy formulations, but also enabled the great majority of less sophisticated voters to know where the parties stood in the down-to-earth practical sense of whether they were in or out of office and whether they were in favor of or opposed to the highly visible national leaders who competed for the presidency.

The smaller size and the greater simplicity of the French party system of the late 1980s compared with that of twenty years earlier are captured neatly in the detailed reports of party identification furnished by the respondents at our 1988 survey as compared with those of 1967, in response to an identical open-ended question. In 1967, 24 categories were required to designate the entire universe of discrete parties mentioned by the sample electorate; 15 categories were adequate to record the partisan field of 1988. ${ }^{10}$

Furthermore, and related to the smaller number of parties claimed by the 1988 respondents as objects of identification, there was less fractionalization of party identification in 1988 than in 1967. On the basis of the Rae (1967) formula for computing party fractionalization, the fractionalization index for party identification in France dropped from .78 in 1967 to .70 in 1988. That is much higher than the level for the United States, with its two-party system, but it is not much higher than the levels for Great Britain during the 1980s, when the appearance of the Social Democratic Party disturbed the hitherto more or less settled contours of the British party system. ${ }^{\text {II }}$

\section{THE COMPOSITION OF THE PARTISAN ALIGNMENT}

We have seen that while the incidence of party identification in France was rising, the political composition of the partisan alignment was shifting. For 1958, at the founding of the Fifth Republic, one cannot even talk about a political alignment. In 1967, the Gaullist party was the dominant political movement, but the balance between leftist and rightist identifiers was more or less equal. By 1988, the Socialist party was the dominant political group and leftist identifiers together outnumbered right-wing identifiers by a ratio of four to three.

Traces of this dual chronological development, in the incidence and com- 


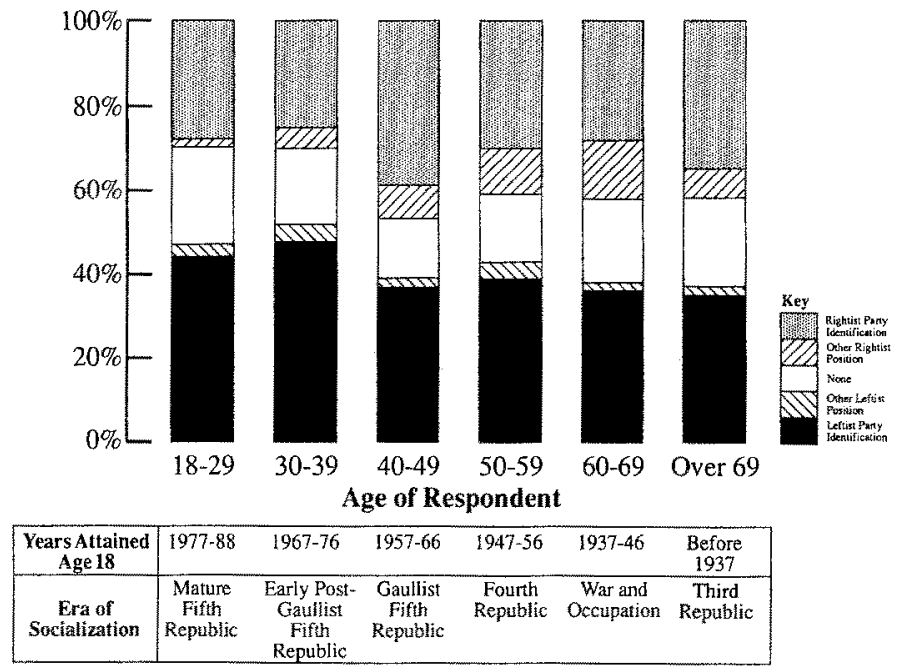

FIG. 1. Basic political orientations by age (France, 1988).

position of party identification, show up clearly when we break down the 1988 distribution of party identification by age. Figure 1 presents that fundamental information, as well as additional data about vaguer forms of political positioning (including references to left-right locations and to political leaders) than literal party identifications, so that we can account for all the political orientations, however expressed, of each age category represented. The age categories themselves are mainly delimited in conventional decade form, without particular regard to the proportion of the total population represented by each category. ${ }^{12}$ At the same time, these age categories broadly match the generational layering that is relevant for an understanding of the development of party identification in France.

As Butler and Stokes (1969, p. 59) succinctly put it, when seeking to understand the profile of party identification by age, one should not ask how old the voters are but rather when it was that they were young. It is during one's early, impressionable years that the seeds of political orientations are planted. National politics can be dominated by vastly different events, conflicts, and personalities from one generation to another, with the result that the basic political orientation of one generation will be quite distinct from that of another. It is in this context that there is a fortunate coincidence between the conventional age categories employed in Figure 1 to indicate how old the voters were in 1988 and the coherence and distinctiveness of the political characteristics of the years when the respondents falling within each of those age categories "were young." 
It is, of course, largely in a poetic sense that we speak here of generations. These are normally thought of as 30-year spans, and not as decades. The term cohort might be more appropriate. Whatever label we use, we should be aware that while Butler and Stokes $(1969$, p. 50n) could make do nicely with four cohorts, we have found it most convenient for our purposes to employ six. That simple difference in analytical categories, as between France and Britain, serves to underscore the more frequent underlying discontinuities in political life in France. In defining our cohorts in terms appropriate to when they were young, we have chosen-as Butler and Stokes did-to do so in terms of "coming of age." Even in this regard, there is a slight discontinuity for France: The voting age was reduced from 21 to 18 in 1974 . We have ignored that change, and simply taken the years when the respondents in the cohort reached age 18 as the era of socialization for each cohort, whether the years involved were before or after 1974 . As the labels on Figure 1 indicate, each age category represents a distinctive "generation" in terms of the defining characteristics of the period when the respondents within that age bracket came of age.

\section{The Incidence of Party Identification by Age}

Confining ourselves first to the incidence of party identification, it is clear that the highest level occurs for the generation that came of age during what we have labeled the Gaullist Fifth Republic. These are the people whose political initiation took place during the years that encompassed the collapse of the Fourth Republic, the return to power of de Gaulle, Algerian independence, battles over the constitution, and the first modern French popular election to the presidency. The voters who were from 40 to 49 years of age in 1988 constitute the "founding generation" (Carmines, 1991) of political conflict in contemporary France, as it is reflected in mass partisan party attachments. We will return to this generation in a slightly different context later in this paper. Here we will add only that when one takes other expressed political locations into account as well as discrete party identifications, the generation of the Gaullist Fifth Republic is the one with the fewest people, proportionately, who have no sense at all of their political location.

The lowest levels of partisanship occur among the older age groups. ${ }^{13}$ These "generations," whose coming of age occurred during the Fourth Republic, the Second World War and the German occupation, and even the Third Republic, are cohorts which, along with their elders of the time, contributed to the very low rate of party identification recorded by Converse and Dupeux (1962) for 1958. Their overall incidence of party identification in 1988, although less than the average, was still well above the 
mean level of 1958, a clear indication that adult French citizens were taking on partisan identifications at a higher rate during the Fifth Republic than they had done earlier.

The intermediate cohorts, in terms of the incidence of party identification, are those who came of age during the early post-Gaullist Fifth Republic and what we have labeled the mature Fifth Republic. The formative political experiences of these two generations naturally differed in their specifics, but they had in common the strong and eventually victorious efforts of the leftist forces to oust de Gaulle and his successors from power. These are the voters whose political environment was characterized most consistently and exclusively by the clarity and simplicity of the two-bloc, pseudo-two-party system that emerged during the mid-1960s. Indeed, the younger of the two cohorts in this category, the one born between 1959 and 1970 , includes children of people from the cohort that came of age during the battles of the Gaullist Fifth Republic. The respondents in our youngest cohort not only had the opportunity to absorb the neat and clear political atmospherics of the mature Fifth Republic, but they also were likely to have experienced parental partisan "pushes" from the people who constitute the founding generation of contemporary French mass partisanship. In that fashion, the intensity of the political conflicts that were the hallmarks of the Gaullist Fifth Republic are wedded to the greater ease of situating oneself in partisan terms that has been characteristic of the years of the mature Fifth Republic.

\section{The Composition of the Partisan Alignment by Age}

Leftist party identifiers outnumber rightist identifiers in four of our six age cohorts. Leftists are most numerous in the generation of the early postGaullist Fifth Republic, and next most prevalent among the youngest of the cohorts, that of the mature Fifth Republic. ${ }^{14}$ In terms of formative political experience, therefore, the years of leftist challenges and defeats during the late 1960s and the 1970s spawned more left-wing party identifiers than the more recent period of leftist electoral victories. The lesser, although still substantial, lead of the left over the right in party identification among the respondents who were in their $50 \mathrm{~s}$ and $60 \mathrm{~s}$ at the time of our survey in 1988 reflects the close balance of left and right party identifications that we recorded in 1967. People in those age groups would have been in their 30s and $40 \mathrm{~s}$ in 1967 and, therefore, contributing to the dead heat as between leftist and rightist party identifiers at that time (within a lower overall incidence of party identification than in 1988). The recorded 1988 levels of leftist party identification among those cohorts may be understood as a reflection of the left-right standoff of 1967, plus an increment of some 5 per- 
cent in favor of the left in harmony with the ongoing leftist surge of the last decade.

It should be noted that if we take into account not only discrete party identifications but also the "other" expressions of political positions that are recorded in Figure 1 (and that overwhelmingly include references to leftright locations), the left-right balance is very close among the respondents who were in their $50 \mathrm{~s}$ or $60 \mathrm{~s}$ in 1988 . The relatively large proportions of rightist respondents who designated themselves in these broader terms reflects the absence in 1988 of surviving partisan referents from the eras during which they came of political age.

The only cohort in which rightist party identifiers outnumbered leftist ones in 1988 is the 40-49-year-old group, which came of age during the Gaullist Fifth Republic. This finding is noteworthy for two reasons. On the one hand, this is the generation that contains most of the people who were young adults in 1968, the year of the now legendary anti-Gaullist mass upheaval that ranks with the Paris Commune and the sit-down strikes of 1936 in the mythology of the French left. The people in this cohort were between 20 and 29 years of age during the events of May 1968. On the other hand, there is a sharp difference in the ratio of leftist to rightist party identifiers as between the 40-49-year-old cohort and the next younger cohort (ages 30-39 in 1988). The 40-49 group is the most rightist generation, while the 30-39 cohort is the most leftist. At least the oldest members of the latter cohort had also been young adults in 1968 . These two aspects of our data raise the question of what the legacy of the 1968 events was in the context of French mass partisanship 20 years later.

To find the answer to that question, we pursued the traces of 1968 more finely than Figure 1 alone permits by examining the distribution of basic partisan identifications within the relevant age groups on an annual basis. This distribution appears in Figure 2, in the form of the proportion of true identifiers with leftist parties less the proportion of true identifiers with rightist parties, by age in 1988, among all respondents in each annual cohort. In order to compensate for the thin case numbers that annualization produces, as well as to smooth out the curve slightly, we employed a threeyear moving average. Each "annual cohort," therefore, is the mean of three adjacent annual cohorts. This procedure yields 3 -year totals that are mainly in the $60 \mathrm{~s}$ and $70 \mathrm{~s}$, and always more than 50 , for respondents ages 30 to 43 in 1988. The totals for respondents ages 44 to 50 are all less than 50 , and include some that are in the low $30 \mathrm{~s}$ and high $20 \mathrm{~s}$.

Despite the risks of sampling error, particularly among the older cohorts displayed, one cannot fail to be impressed by the steep slope of the curve that occupies the middle third of Figure 2. The implications of that slope and its location are so consistent with party identification theory, the local 


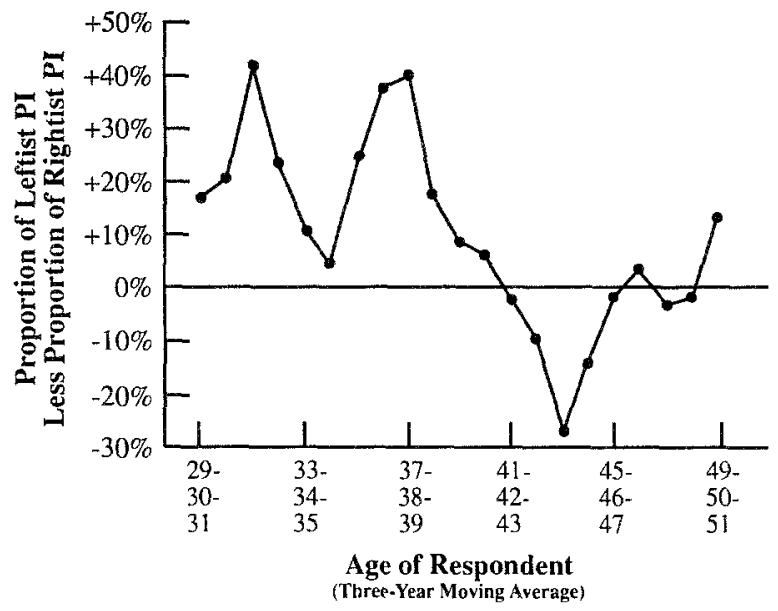

FIG. 2. Trends in balance of party identification among respondents aged 30-50 (France, 1988).

French historical facts, and comparable phenomena that have been reported for the United States that we feel justified, at least provisionally, in setting aside concerns about sampling error and concentrating our attention on the conspicuously coherent display of data.

Let us be clear about where Figure 2 fits into our discussion about the development of party identification in France, and what, more exactly, it tells us. We know that in the past there have been two broad types of partisan configuration. One, which was measured during the late 1960s, showed leftist and rightist party identifiers to be in a more or less equal balance; the other, captured in 1988, was characterized by a clear predominance of leftist identifiers over rightist ones. These may be thought of as two plateaus of different heights.

The residues of these two plateaus, in the form of current (1988) party identifications, appear quite clearly in Figure 1. What does not appear in Figure 1 is the nature and timing of the connection between the two plateaus. It is Figure 2 that supplies us with that information, and it does so with uncommon clarity. The two plateaus are present there in somewhat ragged form, but now we see that they are connected to each other by a steep cliff that was chiseled into the French partisan landscape by people who were between 18 and 24 years of age in 1968. The importance of the 1968 upheaval as a great realigning event is strikingly affirmed. The central role of the youngest voters as the avant-garde of the new alignment is also unambiguously displayed. 
These findings mesh admirably with analogous results reported long ago for the United States. In their classic work, The American Voter, Campbell et al. $(1960$, p. 154) charted the direction of party identification, by year of birth between 1900 and 1930, for some 10,000 cases from seven U.S. National Election Studies conducted between 1952 and 1958. That chart similarly displayed two plateaus of unequal heights joined by a steep cliff (in the Democratic direction) centering on voters born between 1905 and 1912 , indicating strongly that the New Deal realignment had been spearheaded by voters who were between 21 and 27 years old in 1932 .

Converse (1976) later developed that analysis more powerfully and elegantly. On the one hand, he enlarged the case numbers and extended the time frame of the display of party identification by year of birth, and on that basis showed that the age-localization of the depression-era realignment in the United States increasingly lost sharpness of definition with the passage of time, even though it remained apparent from traces into the 1970 s that something important had happened among people who entered the electorate during the $1930 \mathrm{~s}$ (1976, pp. 132-135). On the other hand, by correlating party identifications, by annualized age, with aggregate electoral outcomes for biennial U.S. elections, he showed that the optimal correlations for the period 1952-1958 (the same years charted in The American Voter) occurred for voters between 21 and 22 years of age (1976, pp. 132-137). Between 1964 and 1972, the optimal fit would still have been for age 22 , although for that later period the range of variation was such that any age between 22 and 26 would have been almost as good.

These findings are directly relevant to the interpretation of our French data. Given that the clarity of earlier realignments progressively deteriorates in later expressions of partisanship, our 1988 portrayal of the 1968 French realignment should be more sharply etched than the rendition of the U.S. realignment that appears in The American Voter. While our analysis suffers by comparison with respect to case numbers, it gains in immediacy with regard to the lapse of time between the realigning event and the later distribution of partisan identifications by age. Our 1988 measurements of partisanship occurred a mere 20 years after the realigning upheaval of 1968. The original graph in The American Voter was based on pooled data gathered from 20 to 26 years after the realigning depression, with the result that the contours of the "cliff" rising upward to the new Democratic plateau were already becoming blurred. The best estimate that one can make simply by eyeballing the graph is that the realignment centered on the 24-year-olds of the era. We know from Converse's later analysis, however, that the cutting edge of change was the 21- and 22-year-olds. Our finding for France is that the age range that took the lead in scaling the new leftist rampart was from 18 to 24 , which of course centers on 21 ! It is 
worth recalling in this connection that during the late 1960s and early 1970s the minimum voting age in France was still 21 .

Having placed our French data within a larger, comparative perspective, we are in a position to give a clear answer to the question about the political legacy of the May 1968 upheaval with which we opened this section of our analysis. The 1968 revolt was a realigning event in France analogousat least within a term of 20 years-to the great depression of the $1930 \mathrm{~s}$ in the United States. The leftist dominance in partisan attachments that we found in 1988 had its origins in the May days of 1968, just as the longerterm Democratic party ascendancy in the U.S. emerged from the great depression. ${ }^{15}$

The residues of that new French alignment that we find in the distribution of partisanship, measured 20 years after the aligning event itself, indicate that the shift in the partisan balance that occurred was led by the youngest cohort of voters, just as the youngest voters had spearheaded the New Deal realignment in the United States some 35 years earlier. That is exactly what we would expect on the basis of the theory of partisanship. The youngest voters are, other things being equal, less firmly anchored in the party system than their elders, and they are, consequently, more susceptible to change in reaction to destabilizing shocks to the ongoing party system.

Before we leave Figure 2, there is one more comment to be made, albeit with added caution, as it refers to the right-hand third of the figure, where case numbers are perilously thin. While our 1988 respondents who had been between 18 and 24 years old in 1968 form the cliff that rises to the leftist plateau, there are indications that the slightly older voters, those who had been between 24 and 27 , were actually moving rightward at the same time. That might be merely a trick played by sampling error, but it is in no way inconsistent with the actual events of 1968 . There were, after all, two sides to the 1968 revolt. On the one hand, deep hostility toward the Gaullist regime produced weeks of near-general strikes and massive demonstrations. But there was also a sharp backlash against the disorders associated with the anti-Gaullist demonstrations that produced a right-wing landslide at the legislative elections of 1968 . We know that in the immediate wake of the May events, more voters shifted rightward than moved leftward (Converse and Pierce, 1986, pp. 431-436).

It is not out of the question that while the 1968 revolt put an indelible stamp on the cohort that was between 18 and 27 years old at the time, it did so in internally contradictory ways, with the younger elements of that thin population slice being imprinted by an impulse toward radicalism and the older ones by the backlash. Such an interpretation gains plausibility by the fact that the older segment of the cohort would have been approaching 
the age when young adults begin to take on responsibilities that require order and a stable environment. But this subplot, even if sustained, is only a refinement alongside the central message that emerges from Figure 2: The 1968 upheaval was a realigning event of historic proportions that centered on the youngest voters.

It is important to add, in any case, that the youngest cohort could not alone be responsible for the new leftist predominance in partisanship that was registered in France in 1988, any more than the youngest U.S. voters alone produced the post-1932 Democratic majority. The youngest voters in both countries were only the leading edges of what were broad period effects. The leading edge in France remained finely honed and optimally centered after a lapse of two decades. But the increase in leftist partisanship after 1968 was distributed broadly throughout the entire electorate, and particularly among voters who were too young to have been soixantehuitards (sixty-eighters).

The 1968 upheaval was a major turning point, but other forces also had to be operating on popular political orientations. The most important of these were the decline of Gaullism as the principal pole of attraction on the right, and the growth of the Socialist party into the main magnet on the political left. These dual developments were directly linked to the strategic roles played by the two presidential protagonists of 1965, Charles de Gaulle and François Mitterrand.

\section{Contrasting Leadership Styles}

De Gaulle's defeat at the referendum of 1969, followed immediately by his resignation from the presidency and by his death the following year, left the Gaullist party that had been founded by his supporters in 1958 disoriented and dispirited. The party was surely not leaderless, but its habit of dependence on and obedience to de Gaulle had left it without the experience, temperament, or even mechanisms to produce a new leadership from its own ranks whom the party's numerous heavyweights could support. Pompidou became de Gaulle's immediate heir because he had been his prime minister, and not because he was the choice of calculating party leaders. When Pompidou's death opened up the succession once again, the Gaullists could not find a candidate capable of uniting their party. The candidate who formally ran under the Gaullist banner-Jacques ChabanDelmas - did not outdistance Valéry Giscard d'Estaing at the first ballot of the 1974 presidential election. Gaullist dominance of the right came to an end.

After Giscard's electoral victory, the French right reverted to the splintered state it had been in before it was quasi-unified under the aegis of de 
Gaulle. Gaullist electoral fortunes ebbed during the 1970s and 1980s, while those of their Giscardian rivals gained, until the two right-wing groups were of about equal voting strength. Hardly distinguishable from each other in broad programmatic terms, they were constantly jockeying for preeminence over each other. The Giscardians themselves were a loose federation of rival groupings. The salience that the Gaullist party once enjoyed as the lodestone of the right evaporated.

Even if the Gaullist party had fared better electorally after de Gaulle's departure than it actually did, there is reason to believe that mass attachments to the party would have dissipated at more than a random rate. De Gaulle's withdrawal from the political scene was far more than the passing of a popular party leader. De Gaulle's personal appeal was greater than that of the party that formed to support him. Large numbers of the general's admirers flocked to the Gaullist party because it was identified with him. When de Gaulle left the scene, his party was vulnerable to the loss of that vast conditional element of its foundation. French voters could, did, and still do identify with the Gaullist party for a variety of reasons, but the personal appeal of de Gaulle could not survive him indefinitely.

Even when he was active, de Gaulle did virtually nothing to contribute to the permanence of a Gaullist party. De Gaulle despised parties, and there is no reason to believe that he made any exception for the Gaullists, when they behaved like a party, as opposed simply to supporting his positions, which he always presented as expressions of the national interest. De Gaulle regularly took a stance "above parties," which was hardly conducive to encouraging long-term attachments to any party, even the one that claimed to be his own. It was, in part, de Gaulle's "above-parties" posture that helped him to build personal popular support that was broader and deeper than that earned by the Gaullist party, but that aspect of his appeal made it all the more difficult for his admirers to transfer their allegiance to the Gaullist party, which in any case was bound to emerge diminished once the general was not longer there as a source of reflected glory.

While de Gaulle's disappearance ended the Gaullist hegemony on the right, François Mitterrand's advent to the leadership of the Socialist party set it on a course that culminated with that party's domination of the French left. The Gaullists, at the end of the 1960s, had succeeded in becoming virtually synonymous with the right, only to lose that status during the 1980s, when they found it difficult even to maintain parity of popular support with their Giscardian rivals. The Socialists, by way of contrast, began that same period weaker than the Communists, who were the major political force on the left, but they ended up barely a decade later not only as France's main left-wing party but as its largest party of any kind.

This outcome was the result of the appropriateness of Mitterrand's politi- 
cal strategy for a period when the appeal of the right was waning and antiCommunist sentiment was intensifying. Mitterrand's strategy was to identify the Socialist party unmistakably with the "left" by allying with the Communists under an agreement according to which each party would throw its support at the second ballot of France's two-ballot elections to the candidate of the leftist party that was best-placed to win. ${ }^{16}$ This strategy required a Communist party that was sufficiently respectable not to make such a leftist alliance out of the question (as had been the case in 1969, in the wake of the Warsaw Pact countries' invasion of Czechoslovakia), but still frightening enough to give opposition-minded voters a real incentive to support the Socialists instead. The Communists providentially obliged, by taking only superficial steps to distance themselves from the characteristic features of Russian policy. They remained organizationally in the Stalinist mold and manifested only a slow, incomplete and grudging acceptance of the "Eurocommunist" principles that were rapidly acquiring standing in other Western European Communist parties. In these circumstances, the Socialist party became the main point of attraction for voters who sought radical economic and social reforms but who also distrusted the Communist party.

As the main beneficiary of discontent with right-wing rule, the Socialist party regularly outdistanced its Communist allies at the first ballot of legislative elections, and the terms of the alliance became increasingly favorable to the Socialists. What was in principle a system of mutual assistance became mainly a conduit for the flow of Communist votes in support of Socialist candidates at the second ballot, as the proportion of districts in which Communists ran ahead of Socialists at the first ballot decreased during the 1970 s and 1980 s.

Furthermore, Mitterrand had no reservations about trying to convert whatever personal appeal he could muster to the advantage of the Socialist party. While de Gaulle styled himself as above parties, Mitterrand was conspicuously partisan. He worked and schemed tirelessly, not only in his party but also for his party. In this regard, Mitterrand's behavior could hardly have been more different from that of de Gaulle, and the results in terms of personal as compared with partisan political identifications are strikingly different as well. In 1968, shortly after the Gaullist party won the greatest electoral victory of its history, almost half as many respondents in the Converse/Pierce survey claimed to be "Gaullists" or identified with "De Gaulle's party" as professed an identification with some nominal variant of the Gaullist party. At our 1988 sample survey, conducted in association with Mitterrand's triumphant reelection to the presidency, a mere handful of respondents replied that they identified with "Mitterrand" or "Mitterrand's party," as compared with the more than one third who claimed an attachment to the Socialist party. 
The Socialist party had the good fortune of being in the ascendancy when the level of political interest was rising, partisan choices were becoming simpler and clearer, familial political socialization was widening, and the overall incidence of party identification was increasing. During the late 1960s, the French Socialist party was somewhat less visible than the Gaullist UNR and considerably less visible than the Communist party (Converse and Pierce, 1986, p. 62). By 1988, the Socialist party was almost surely the most visible party on the French political horizon. Exercising the widest field of attraction, the Socialists were in a position to profit most from the increasing proportion of citizens that were receptive to partisan persuasion. The main source of Socialist party identifiers was, of course, the successive younger "generations," but the data in Figure 1 show that the left had also won at least the temporary allegiance of voters from older generations that had been immune to partisan appeals in their youth.

\section{DISCUSSION}

As we indicated at the outset of this paper, our investigation has two sets of implications: one relating specifically to the French political landscape, the other to the theory of elections that centers around the concept of party identification. With regard to the former, the main lesson is that the partisan alignment whose development and contours we have traced was vulnerable to any undoing of the conditions that created it. With respect to the theory of elections more broadly, our findings lead to some concluding comments about the conditions of a basic partisan alignment.

\section{The Fragility of the Partisan Alignment}

The two most prominent characteristics of the 1988 French partisan alignment are that it was comparatively new, having been formed only during the two decades between 1967 and 1988, and that its political composition was shaped mainly by the partisan identifications of the younger citizens. These two features, which are related to each other, mean that the foundation of the alignment was less than solid and its duration uncertain. The gradient in strength of party identification by age was the same in France in 1988 as it normally is in a developed system: Party identification was weakest among the young and generally intensified with age, except for the most elderly cohort. ${ }^{17}$ The probability that people would abandon or switch their partisan attachment was, therefore, highest for the voters under 40 years of age who contributed so heavily in 1988 to both the new equilibrium level of party identification in France and its sharply leftist orientation. Furthermore, inasmuch as it is not biological age per se but rather length of systemic experience that affects the intensification of party 
identification, the predominantly leftist party identifications acquired in recent years by older members of the electorate were similarly more susceptible to change than they would have been if they had been acquired earlier in life.

The factors that could contribute to disturbing the 1988 alignment were the same as those that were for so long the main obstacle to the formation of any partisan alignment at all: the tendency for the political elites to keep tinkering with the political supply and obscuring the objects of partisan choice. Those propensities are more characteristic of rightist and centrist leaders than of leftists, but no segment of the political spectrum has been immune from splintering, the launching of new parties, or the formation of temporary electoral alliances under new names.

The risk was not that the incidence of party identification would recede to its lower levels of two or three decades earlier. That is not impossible, but it is highly unlikely, given that party identification had reached the equilibrium level, and in view of the weakening of the reticence norm that formerly impeded the intergenerational transmission of partisanship (Percheron, 1989).

The greater probability was an increase in instability of partisan identifications at the individual level beyond the expected rate for a party system of the size of the French one. If new parties continued to emerge, old ones splintered, fractious leaders complicated the partisan field, and complex coalition strategies obscured the meaning of electoral choices, it could be expected that movements into and out of partisan identifications would accelerate, along with switches from identification with one party to identification with another.

The party that had the most to lose from such a development was, of course, the Socialist party, as it was the one that gained the most during the years when the party system stabilized and the incidence of party identification rose. In these circumstances, it was particularly important for the party to contain its divisions and leadership rivalries, notably in the eventual selection of a successor to François Mitterrand as party leader and presidential candidate. If the Socialists could manage their internal tensions without damaging the clarity and constancy of their public image, they had a chance to succeed where the right in general and the Gaullists in particular had failed so badly after the departure of de Gaulle.

A measure of the political treasure that the rightist parties squandered after 1969 appears in the data displayed in Figure 1 for the respondents who were in their $40 \mathrm{~s}$ in 1988 , whom we have labeled the generation of the Gaullist Fifth Republic. They constitute the only cohort that is more rightist than leftist in discrete party identifications, and the rightist party identifiers in that cohort are more strongly attached to their parties than either 
leftists or rightists of any other cohort. ${ }^{18}$ The squabbling right-wing parties were less attractive to the following generations, and they entered into a long series of hollow years.

But if there was some possibility that the French Socialist party after 1988 might avoid the fate of the Gaullists after 1968, it is also true that they could control their own fortunes only to a limited extent. The main argument of this article is that the generation of a partisan alignment in France by 1988 was the result of a set of systemic factors having to do with the simplification, clarification, and stabilization of the entire party system. This was a result to which all the major parties contributed, even if it was the Socialists who by 1988 had most prospered from it. For twenty years, there were symmetrical electoral alliances on both left and right, and comparatively homogeneous governments faced similarly united oppositions. By 1988 , when we took the reading of the distribution of partisan identifications that both reflected and contributed to that partisan structure, the pseudo-two-party system was already unraveling, and it would continue to do so. As the dominance of the two-bloc system eroded, new political entrepreneurs could be expected to multiply their efforts to upset the fragile equilibrium that had been two decades in the making.

\section{The Conditions of a Partisan Alignment}

This article directs attention to the question of how a partisan alignment is formed where there was none before, even though there was an ongoing party system. This is a different issue from the one that has tended to attract the interest of students of party systems in recent years. These have been concerned primarily with the patterns and processes of dealignment or realignment, both of which are developments that assume the prior existence of some kind of alignment from which the electorate might deviate.

The distinct object of our investigation has led us to focus on the attributes of the ongoing party system, and more particularly, on the changes that occurred in it more or less coincidentally with the development of not a new but rather an original partisan alignment. That, too, is a departure from the main features of most contemporary accounts of partisan alignments. These attribute central importance to basic social cleavages or the crystallization of a powerful new issue agenda (Dalton, 1988; Carmines, 1991).

We do not mean to suggest by omission that social cleavages are not fundamental to the party system, or that major issues are irrelevant to the electoral fortunes of the various parties that populate that system. Indeed, we have emphasized the critical role of the 1968 upheaval in the emergence of the new alignment, and the primacy of the youngest voters in 
shaping a new partisan configuration. Issues were certainly not foreign to those major events, but while they eventually had to be expressed in concrete form for policy-making purposes (Converse and Pierce, 1986, pp. $730-738$ ), they were highly diffuse and buried in broader ideological slogans while the May 1968 events were actually unfolding. We do, however, believe that to focus on the nature of the cleavages or the substance of the issues would be to put the cart before the horse. A prior condition of the operative effect of social cleavages and major issues on the fate of the parties in any system is that the parties be clearly perceived by the voters in those terms. In France, the site of our investigation, the fundamental societal cleavages and major issues have been present for a long time, but they did little until recently to stabilize the party system or to contribute to the formation of a partisan alignment. We have, therefore, concentrated on the clarity and constancy of the party system rather than on the character of the parties' social support (except for age) or on the content of current issues. The simplification and stabilization of the party system made the development of a partisan alignment possible, and an alignment would have been formed whatever the issues might have been, although these naturally affect the balance of underlying partisan strength.

The importance of the structure and character of party systems for the development of partisan alignments will be increasingly apparent as the numerous new democratic systems that are in the process of formation struggle to find some sort of stable foundations. The new regimes that are emerging in the wake of the current sweep of global democratization will be prey to a host of problems inherited from the past and preparatory for the future. They can, in the best of circumstances, be expected to be highly unstable. They are the more likely to achieve some stable flow of communications between the mass electorate and the governing elites if these latter show restraint and self-discipline in their control of the supply side of the partisan market.

Acknowledgment. I am grateful to my long-time friend and collaborator, Philip E. Converse, for his invaluable advice.

\section{NOTES}

1. The actual comparison was between French voters from 1967 to 1968 , and U.S. voters from 1956 to 1958 , and from 1958 to 1960 . Those were years when net aggregate electoral stability was atypically high for France and low for the U.S., so some caution is called for in generalization from the findings, but the underlying message that constancy of partisan choice requires constancy of partisan offerings is irrefutable.

2. This does not mean that every party had an equal probability of winning the support of the voters who were not already attached to a particular party. For many people who did 
not identify with a discrete party, certain other parties-notably the Communist partymight be pariahs. Still other people might be guided by their religious outlook, or a sense of left-right location, or sympathy for certain social groups (workers, small business). But for those people, the electoral problem included the far from trivial task of identifying which of the large array of contending parties most closely matched whatever more general, politically relevant orientation they might have.

3. For the contrary view, see Lewis-Beck (1984, pp. 428-433, 447). Charlot (1986, p. 6) reports the results of a series of French surveys purporting to measure the incidence of party identification. Most employed the interview method of giving the respondents a list of parties from which to choose and produce characteristically inflated results. Charlot does not report the question wording, but consistency here is also essential. For the question wording used to measure "partisan proximity" in France in 1978, see Capdevielle et al. (1981, p. 22n). For additional considerations concerning problems of ascertaining party identification in France, see Converse and Pierce (1986, Chap. 3, n.7).

4. The author is happy to acknowledge the support of grant SES- 8801639 from the National Science Foundation, as well as further support from SOFRES, the French Cultural Services of Chicago, Ilinois, and The French-American Foundation.

5. In order to eliminate the possibility that interviewers might translate unintelligible reports of partisan attachments into some credible version, Converse and Pierce contracted for special interviewer training for their surveys in the late 1960s. Resource limitations ruled out special interviewer training for the 1988 study, but the printed questionnaires used by the interviewers contained this special instruction, alongside the question relating to party identification, and printed in large, conspicuously boldface type: "Enquêteur: Ne Rien Suggérer. Noter de façon très précise ce que vous dit l'interviewé même si ce n'est pas le nom d'un parti." (Interviewer: Do not suggest anything. Note down exactly what the respondent tells you even if it is not the name of a party.)

6. Converse"s calculations were based on a turnover model that assumed the probability of a person acquiring a partisan attachment was .8 if that person was raised in a partisan family and only .5 if the person was reared in an apolitical family. Those conditional probabilities had been empirically determined for both France and the United States during the 1950s (Converse, 1969).

7. A literal application of Converse's turnover model, taking the 30-year lapse between 1958 and 1988 as a single generation, and assuming that the incidence of party identification in 1958 was 53 percent, produces a 1988 level of 66 percent, somewhat lower than our reported incidence. But given changing patterns of familial political socialization during recent decades (Percheron, 1989), we should not be surprised that party identifications would accumulate at a somewhat faster rate than Converse's model assumes.

8. These matters are spelled out in detail in Converse and Pierce (1986, Chap. 3).

9. Percheron (1989, p. 84) reports that between 1975 and 1989 , there was a dédramatisation of politics within the family: "Political choices departed from everyone's secret garden, from the domain of silence."

10. There is some room for debate over what is a "discrete party." For 1967, we included references to "Gaullist" and "Giscardian" in the partisan inventory; for 1988, we excluded references to leaders. For both years, we have excluded references to left-right locations and to groups that are clearly not parties.

11. See Converse and Pierce (1986, pp. 91-93) for a comparison of the fractionalization of the French party system of the late 1960s with that of the party systems of the U.S., Great Britain, and the Netherlands at more or less the same time period.

12. On the general question of the criteria for establishing age categories for political analysis, see Percheron (1988). 
13. Except for the group ages 18 to 20 in 1988, not shown separately in Figure 1, among whom less than 63 percent identified with a party.

14. But not, however, among the very youngest. Among the thin population slice ages 18 to 20 , right-wing identifiers outnumber leftists.

15. The protest movements in the United States during the 1960s had a different kind of effect on the distribution of partisanship. Jennings and Markus (1984) found that the main political difference between graduating high school students in 1965 and their parents was that the former were less likely to identify with any party, a difference that endured into the early 1980s. But as the comparison between children and parents connotes, that was essentially a generational effect, without any marked resonance among other age groups. A graphing of the proportion of persons in the U.S. having a party identification (i.e., excluding leaners and independents) in 1988, by annualized age, shows no "cliff" connecting two plateaus of different heights. Of course, the protest movement in the U.S. did not have the magnitude, breadth of social support, ideological inspiration, concentration, and explosiveness that characterized the French upheaval of May 1968.

16. See Schlesinger and Schlesinger (1990) for a discussion of how French parties adapt to the exigencies and opportunities of the two-ballot electoral system.

17. The only exception was that 40-49-year-old identifiers felt closer to their parties than the 50-59-year-olds, largely because of the strength of right-wing partisan attachments within the "founding generation."

18. This helps to explain the larger proportion of rightist than leftist identifiers in 1988 among the 18-20-year-olds, who are among the children of the most right-wing 1988 cohort.

\section{REFERENCES}

Butler, David, and Stokes, Donald E. (1969). Political Change in Britain: Forces Shaping Electoral Choice. New York: St. Martin's.

Capdevielle, Jacques, et al. (1981). France de Gauche Vote à Droite. Paris: Presses de la Fondation Nationale des Sciences Politiques.

Carmines, Edward G. (1991). The logic of party alignments. Journal of Theoretical Politics 3: 65-80.

Charlot, Jean (1986). La transformation de l'image des partis politiques français. Revue Française de Science Politique 36: 5-13.

Converse, Philip E. (1969). Of time and partisan stability. Comparative Political Studies 2: 139-171.

Converse, Philip E. (1976). The Dynamics of Party Support: Cohort-Analyzing Party Identification. Beverly Hills: Sage (Volume 35, Sage Library of Social Research).

Converse, Philip E., and Dupeux, Georges (1962). Politicization of the Electorate in France and the United States. Public Opinion Quarterly 26 (Spring). Reprinted in: Campbell, Angus, Converse, Philip E., Miller, Warren E., and Stokes, Donald E. (1966). Elections and the Political Order. New York: John Wiley and Sons.

Converse, Philip E., and Pierce, Roy (1986). Political Representation in France. Cambridge, MA: Harvard University Press.

Dalton, Russell J. (1988). Citizen Politics in Western Democracies: Public Opinion and Political Parties in the United States, Great Britain, West Germany, and France. Chatham, NJ: Chatham House.

Fougeyrollas, Pierre (1963). La Conscience politique dans la France contemporaine. Paris: Denoël. 
Jennings, M. Kent, and Markus, Gregory B. (1984). Partisan orientations over the long haul: Results from the Three-Wave Political Socialization Panel Study. American Political Science Review 78: 1000-1018.

Lancelot, Alain (ed.) (1986). 1981: Les Elections de lalternance. Paris; Presses de la Fondation Nationale des Sciences Politiques.

Lewis-Beck, Michael S. (1984). France: The stalled electorate. In Russell J. Dalton, Scott C. Flanagan, and Paul Allen Beck (eds.), Electoral Change in Advanced Industrial Democracies: Realignment or Dealignment? Princeton, NJ: Princeton University Press.

Lipset, Seymour Martin, and Rokkan, Stein (1967). Party Systems and Voter Alignments. New York: Free Press.

Mair, Peter (1989). The problem of party system change. Journal of Theoretical Politics 1: 251-276.

Percheron, Annick (1988). Classes d'âge en question. Revue Française de Science Politique 38: 107-124.

Percheron, Annick (1989). Peut-on encore parler d'héritage politique en 1989? In Yves Mény (ed.), Idéologies, partis politiques et groupes sociaux. "Pour Georges Lavau." Paris: Presses de la Fondation Nationale des Sciences Politiques.

Rae, Douglas W. (1967). The Political Consequences of Electoral Laws. New Haven, CT: Yale University Press.

Schlesinger, Joseph A., and Schlesinger, Mildred (1990). The reaffirmation of a multiparty system in France. American Political Science Review 84: 1077-1101.

Sondages (1952). No. 3. Numéro Spécial.

Williams, Philip M. (1964). Crisis and Compromise: Politics in the Fourth Republic. London: Longmans. 